\title{
TEACHERS' PERCEPTIONS OF THE CHALLENGES IN THE ONLINE EFL TEACHING: A REVIEW OF PREVIOUS STUDIES
}

\author{
Muthi'ah $^{1}$, Muhammad Syahruddin Nawir ${ }^{2}$, Annisa Shofa Tsuraya ${ }^{3}$ \\ 1,2,3Universitas Islam Negeri Alauddin Makassar \\ 1,2,3Jalan H. M. Yasin Limpo No. 36 Romang Polong-Gowa, Sulawesi Selatan \\ Email: muthiah.rahim@uin-alauddin.ac.id ${ }^{1}$, muhammad.syahruddin.nawir@uin-alauddin.ac.id², \\ annisa.tsuraya@uin-alauddin.ac.id ${ }^{3}$
}

\begin{abstract}
:
Technological advances and the COVID-19 have accelerated the shift from traditional learning to online learning. Educational institutions have no choice but to convert the classroom setting into online classes. When teaching online, EFL teachers may have encountered challenges. This paper aims to review some previous studies on the teachers' perceptions of the challenges in online EFL teaching, in Indonesia and other countries. This study employs library research. The result shows that challenges occurred during the implementation of online EFL teaching and learning. In other countries such as Korea, Thailand, Iran, China, and Saudi Arabia, the challenges are mostly related to the students' learning process including the time and class management. On the other hand, in Indonesia, the challenges are more complex. Lack of experience with the online teaching methods and the limitations regarding the adequate internet facilities become the challenges that are most complained by the teachers.
\end{abstract}

\begin{abstract}
Abstrak:
Kemajuan teknologi dan COVID-19 telah mempercepat peralihan dari pembelajaran tradisional ke pembelajaran online. Institusi pendidikan tidak punya pilihan selain mengubah pengaturan kelas menjadi kelas online. Saat mengajar online, guru EFL mungkin menghadapi tantangan. Makalah ini bertujuan untuk meninjau beberapa penelitian sebelumnya tentang persepsi guru tentang tantangan dalam pengajaran EFL online, di Indonesia dan negara lain. Penelitian ini menggunakan penelitian kepustakaan. Hasil penelitian menunjukkan bahwa tantangan terjadi selama pelaksanaan pembelajaran EFL online. Di negara-negara lain seperti Korea, Thailand, Iran, Cina, dan Arab Saudi, tantangannya lebih banyak terkait dengan proses belajar siswa termasuk waktu dan manajemen kelas. Di sisi lain, di Indonesia, tantangannya lebih kompleks. Kurangnya pengalaman dengan metode pengajaran online dan keterbatasan fasilitas internet yang memadai menjadi tantangan yang paling dikeluhkan oleh para guru.
\end{abstract}

\section{Keywords:}

Teacher Perception, Online Teaching, Challenges, EFL

How to Cite: Muthi'ah, Nawir, M. S., \& Tsuraya, A. S. (2021). Teachers' Perceptions of the Challenges in the Online EFL Teaching: A Review of Previous Studies. Lentera Pendidikan : Jurnal Ilmu Tarbiyah dan Keguruan, 24(2), 215-223. https://doi.org/10.24252/lp.2021v24n2i5. 


\section{INTRODUCTION}

The impact of technological advances and innovations has affected the implementation of the EFL teaching and learning strategies. In the past, when teachers mostly handled the classes face-to-face, the EFL teaching process was limited to direct lecturing and group discussion. As educational technology began to exist, EFL teaching and learning process started integrating technology as instructional tools, such as visual aids and audio players. Many EFL classrooms have adopted recent technologies such as online presentations and online applications (Adnan, Ahmad, Yusof, \& Kamal, 2019). In recent years, technological innovations have allowed everyone around the world to learn through online classes. Higher educational institutions provide learning applications such as Learning Management System (LMS) to support the succession of online classes.

Besides, the existence of the coronavirus (COVID-19) pandemic has also impacted the EFL teaching process. In preventing the spread of the virus, the teaching and learning process in every educational institution needs to be carried out in a distance by solely relying on technology. The COVID-19 pandemic has accelerated the full integration of technology in EFL teaching and learning (Hakim, 2020). All universities were advised to turn traditional learning into online one for a longer time. Online learning is defined as a set of learning activities in a subject delivered through network access and the exchange of knowledge (Atmojo \& Nugroho, 2020).

Because all of the sessions were to be held online, English teachers needed to be able to use and adapt online tools in the classroom. Teachers have many options of application that they can use to support EFL teaching. In EFL teaching, some online applications such as Zoom, Google Meet, Google Classroom, Kahoot, Quizizz, and other online applications can be useful as e-learning media. Sakkir, Dollah, \& Ahmad (2020) researched the favorite learning applications in the era of the COVID-19 pandemic. Based on the result, most teachers prefer to use Zoom, Whatsapp, and LMS as e-learning media.

Throughout 2020, English language teaching was rapidly changed, with the effective and distinctive implementation of technology to enhance the learning and teaching process (Hakim, 2020). Several benefits have been gained from the online EFL teaching process. Firstly, studying can be done at any time and from anywhere, allowing more time to think and react as well as increase flexibility in learning (Xia, Fielder, \& Siragusa, 2013). Secondly, online learning helps EFL teachers to conduct interesting and fun learning activities using various online applications, as well as promoting autonomy learning (Apriani \& Hidayah, 2019). Thirdly, the use of technological interaction tools will support both students and teachers by, for example, making current primary source materials accessible and assisting with the speaking/ writing data collection process (Hakim, 2020).

Despite all those benefits, several studies about online EFL learning focused on investigating the challenges that the EFL teachers encountered during online learning. Therefore, this paper aims to review the challenges based on the results of the previous studies which were conducted in 2020.

\section{RESEARCH METHOD}


This study is conducted using a qualitative research design in the form of library research. Library research is a type of research in which the data are obtained from various library sources, such as textbooks, articles, thesis, research reports, newspapers, etc (Zeid, 2004). In other words, library research is a study that elaborates a problem by solely depending on an in-depth review of the relevant sources. The sources of this research were mostly research articles. There are 9 articles of the previous related studies selected to support this article. All of the studies were conducted in 2020. Glasser and Strauss in Flick, Kardorff, \& Steinke (2004) suggest that benefit of the library research is the availability of a large number of reference materials in terms of time, space, and other properties. Based on the statement, it can be assumed that the data of the library research are highly accessible without time and space restrictions.

The process of collecting and analyzing the data is not that simple. In collecting the data, the researcher needs to carry out some steps. First, the researcher needs to identify and locate relevant information about the topic being discussed. After that, the researcher analyzes the data and then develops and shares ideas about the data (Flick, Kardorff, \& Steinke, 2004). Moreover, in analyzing the data, the researcher can employ two techniques of data analysis, namely, descriptive analysis and content analysis. Descriptive analysis is carried out by referring to specific citations regarding the results of previous research and studies (Surakhmad, 1990). On the other hand, content analysis is about making replicable inferences of the collected data by sticking to the context (Bungin, 2007).

\section{RESULTS AND DISCUSSION}

\section{Teachers' Perceptions of the Challenges in Online EFL Teaching}

There have been several studies about the challenges of online teaching, especially during the pandemic. Researchers in different countries have conducted the studies. The findings of the related studies are significant for the improvement of EFL online learning. The success of online EFL learning is determined by the teachers' ability to evaluate the process and discover the challenges to find strategies that can minimize the problems. This review paper focuses on the previous investigations on the teachers' perception of the challenges in online EFL teaching.

In exploring the challenges and strategies of the online EFL teaching in Korea, A survey analysis was conducted using a snowball sampling technique (Bailey \& Lee, 2020). The data were collected from $43 \mathrm{EFL}$ instructors who were categorized into three different groups of teaching experience: 19 instructors with no prior experience teaching online, 14 instructors who have taught online for at least one semester or two years, and 10 instructors with more than 12 years of experience in online teaching. The study concludes that instructors who were unfamiliar with online education expressed frustration with elearning and other computer-based classroom practices. They had difficulties in initiating the types of activities that were made through online communication. In addition, most of the instructors reported that they felt challenged by having to deal with technical problems when using the online teaching tools. Therefore, it is suggested that universities can provide specific programs to improve the skill and knowledge about how to use technology 
in the online classroom effectively.

Khatoony \& Nezhadmehr (2020) conducted a study using exploratory sequential mixed-methods to examine the EFL teachers' challenges in integrating technologies during Coronavirus condition in Iran. The research participants were $30 \mathrm{EFL}$ teachers ranging in age from 20 to 50 consisted of 18 males and 12 females. They were English language teachers at English language schools of Tehran, Hamedan. The teachers had different teaching experiences and taught various levels of English. The results reveal that the main problem of online teaching was the speed of the internet. Besides, the teacher claimed that the students could not concentrate on the materials during the online teaching. The teacher also questioned the reliability of the students' work because it is straightforward to get answers from the internet these days. In addition, the study suggests that the teacher should be able to commit to the online classes fully. They need to do their best to assist the students in performing their responsibilities and help them adapt to potential pressures that occur in the virtual teaching and learning process.

Another mixed-method study was done by Todd (2020), identifying the problems of online teaching as perceived by 52 EFL teachers at King Mongkut's University of Technology Thonburi, Thailand. By giving questionnaires and conducting interviews, the researcher found several problems regarding the shift from the classroom to online teaching. Based on the data, the problems are mostly related to the students' learning. First of all, the teachers thought that they spent a lot of time checking emails or LMS to see if the students' followed-up on the online learning. Another problem is the great amount of time that the teachers spent checking the students' assignments. The teachers complained about their sore eyes from taking too long to check the students' work in front of the computer. The teachers also found it difficult to stimulate the students to focus on the subject during online teaching, and the process of evaluating the students' behaviour becomes problematic. The teachers were aware that they needed to find certain ways to increase the students' interaction in the virtual learning process, especially when surrounded by distractions such as TV, online games, etc.

Moreover, Gao \& Zhang (2020) did a small but in-depth study by interviewing three EFL teachers from a university in Northern Chinese city. The study aims to determine that EFL teachers thought about the benefits, drawbacks, and challenges of online EFL teaching. It reveals that the teachers perceived online teaching in both positive and negative ways. The negative perceptions refer to the challenges that they had to face during online teaching. The first challenge is the lack of adequate information technology literacy for online teaching. Teachers' knowledge and skills in information technology are restricted to integrating digital technologies into classroom teaching, with little knowledge and skills in online teaching. The second issue is insufficient network conditions for online teaching and learning. The entire online class session will be forced to pause if a network error occurs. The third problem is poor class management. Teachers are unable to track students efficiently \& give timely input through eye contact.

Furthermore, a related study was also conducted in Saudi Arabia with 50 English instructors from seven different nationalities. All the participants have a Master's degree 
in English language teaching and actively teach English to students at various levels (beginners to advanced levels). The instructors were interviewed through Zoom meetings to address the challenges faced by teachers in online classes during the COVID-19 pandemic. Despite the instructors' positive attitude towards online teaching, they have experienced some technical issues with the students, material development, limited teaching time due to management tasks, and lack of evaluation tools. The implication of the study is to raise awareness of the educational institution to reshape the curriculum and evaluation methods for online teaching (Hakim, 2020).

Based on the recent studies conducted in five different countries, it can be concluded that the challenges are mostly related to the teachers' concerns regarding the students' learning process and the teachers' time management. Material development and students' technical issues are the challenges that the EFL teachers frequently address. The sudden implementation of virtual teaching due to the pandemic has caused less preparation in reformatting the materials into the online teaching setting. The teachers also complain about students' engagement in online teaching and the time they need to evaluate students' work. However, network problem and online class management are also addressed as the actual challenges of online teaching and learning

Having identified the challenges, most researchers also provide some constructive suggestions directed to educational institutions, teachers, and curriculum and material developers. First, educational institutions should provide certain training programs to develop the teachers' capacity and knowledge about technology and online teaching. The teachers should be more creative in presenting the materials to be able to engage students' interaction in the online learning process. Lastly, the curriculum and teaching materials need to be reshaped to accommodate the online teaching pattern.

\section{Teachers' Perceptions of the Challenges in the Online EFL Teaching in Indonesian Context}

The Indonesian education system does not accommodate online teaching. Before the pandemic, most of the EFL teaching processes were administered in face-to-face interaction in the classroom. However, in response to the COVID-19 outbreak, all the educational institutions have no choice but to convert the classroom setting into online classes. The sudden implementation of online learning as the substitute for the face-to-face learning setting encourages some Indonesian scholars in English teaching to investigate and evaluate its process. The aims are to identify the challenges and to suggest some strategies that can be used to improve the virtual teaching process.

A qualitative study was conducted about the EFL teachers' perception of the use of ICT in the teaching and learning process. The researcher distributed the questionnaires to five English teachers from three different schools in Ambarawa and had a semi-structured interview with the respondents. The findings indicate that most of the teachers agree that the use of ICT can make the class more interesting and flexible. However, the teachers argue that ICT can only be effective if integrated into Blended Learning. The study also revealed the challenges of using ICT in online learning. The challenges that are perceived by the teachers are the lack of high-quality technological tools and the teachers' confusion 
in choosing the best application that fits the students' ability (Maulana, 2020).

Another qualitative study about the challenges of online EFL learning was done by (Putra, 2020). The research participants were elementary school teachers in Surakarta. The researcher used a hermeneutic phenomenological study to identify and interpret the respondents' experiences, feelings, and opinions based on the interview. According to the teachers, they find some difficulties in teaching English during the pandemic. Teaching elementary school students is quite different from teaching teenagers and adults. According to the teachers, they have difficulty making the best schedule for the students and their parents. In the teaching and learning process, the students must be accompanied by their parents when using smartphones or notebooks. The problem arises when the learning schedule coincides with the parents' working hours. Besides, the teachers also have a problem choosing the best online platform that can facilitate the learning process of elementary students. The teachers decided to use three different applications, namely Whatsapp, Youtube, and Google Form. The other problem is related to the internet connection and data. Online learning needs a stable internet connection and enough data. The teachers and parents have to provide a large amount of data for the teaching and learning process.

Moreover, Atmojo \& Nugroho (2020) conducted a study on 16 EFL teachers from 16 different secondary schools in various cities in Indonesia. The researchers used openended questionnaires and interviews to investigate the challenges that the students dealt with in online EFL learning. The result shows that the problems of virtual learning are not only encountered by the teachers, but also the students and the parents. Even though the study covers all of the problems, but the information was only gained from the teachers' perceptions. The problems of the students are: 1) financial condition that makes it difficult for them to have their own smartphone, 2) unstable internet connection, 3) unfamiliarity with the online application and platforms, 4) poor punctuality regarding the attendance and assignment submission, and 5) load of homework they need to do during the online learning. On the other hand, the teachers also find some problems regarding the online learning process. First, some teachers have lack experience and knowledge in creating materials that can be delivered within the allotted time. Second, the teachers find it difficult to engage passive and low-motivated students in the online learning setting. Third, the teachers confess that they are not ready for the online learning that needs to be fully conducted because of the pandemic. Fourth, due to the absence of physical interaction, the emotional connection between the teachers and the students is not as strong as it should be. Besides, the parents have difficulty monitoring their children's learning involvement in online classes because they have work.

A further study was carried out by Tukan (2020) that investigated the challenges of using online applications in EFL teaching and to suggest some strategies that can be used by the teachers to solve the issues during online teaching. The study involved five EFL teachers from different senior high schools and regions in Java. The data were collected by using interviews. The result indicates that there are five challenges encountered by the EFL teachers: 1) difficulties in operating the online applications, 2) providing materials 
that are easily understood by the students during the online learning, 3) finding the best teaching method, 4) combining the materials with a suitable application, and 5) motivating the students to study from home and getting the parents to understand the situation. The study also reveals some strategies that can be used by the teachers to solve the problems: 1) in order to understand how to operate the online application, the teachers need to watch the tutorial video of operating the application, 2) the teachers need to choose the application that supports the teaching materials, 3) if possible, the teachers can rearrange the schedule that allows the parents to control and help the students' learning process, 4) teachers should be able to provide creative and enjoyable materials to prevent the students from boredom, 5) teachers should give simple materials and assignments.

Based on the review of the previous studies in Indonesia, it can be concluded that the teachers mostly have similar problems. Lack of experience or unfamiliarity with the virtual teaching methods and the limitations regarding the adequate internet facilities become the challenges that are most complained by the teachers. The teachers' constructive perceptions of the challenges will be surely significant for the evaluation and improvement of online EFL teaching. Furthermore, the education policy in Indonesia should be adjusted to online teaching and learning, so that the limitations of online teaching skills and internet facilities can be overcome.

\section{CONCLUSION}

The previous studies show that although online teaching can substitute classroom learning during the pandemic, there are several challenges encountered by EFL teachers when implementing online teaching. In other countries such as Korea, Thailand, Iran, China, and Saudi Arabia, the challenges are mostly related to the students' learning process as well as the teachers' time and class management. On the other hand, in the Indonesian context, the challenges are more complex. Lack of experience or unfamiliarity with the online teaching methods and the limitations regarding the adequate internet facilities become the challenges that are most complained by the teachers.

Moreover, the studies also offer some constructive suggestions directed to educational institutions, teachers, and curriculum and material developers. Educational institutions should provide certain training programs to develop the teachers' capacity and knowledge about technology and online teaching. The teachers should be more creative in presenting the materials to be able to engage students' interaction in the online learning process. Moreover, the curriculum and teaching materials need to be reshaped to accommodate the online teaching pattern. In the Indonesian context, the education policy should be adjusted to online teaching and learning, so that the limitations of online teaching skills and internet facilities can be resolved.

Furthermore, it can also be concluded that most of the previous studies on the teachers' perceptions of the challenges in the EFL online teaching used qualitative approach. The main instruments used in the studies were questionnaires and interviews. The qualitative approach was used to explore in-depth elaboration of the findings. Mixedmethod was also employed in the area of the study. The participants of the studies are 
varied from elementary school teachers to EFL instructors in universities. Specifically, in the Indonesian context, the related studies at the higher education level are still limited.

\section{REFERENCES}

Adnan, A. H. M., Ahmad, M. K., Yusof, A. A., \& Kamal, M. A. M. (2019). English Language Simulations Augmented with 360-degrees spherical videos (ELSA $360^{\circ}$ - Videos): "Virtual Reality" real life learning! International Invention, Innovative \& Creative Conference Series 1, 82-88. https://www.researchgate.net/publication/3329102 23_English_Language_Simulations_Augmented_with_360-degrees_spherical_vide os_ELSA_360-_Videos_'Virtual_Reality'_real_life_learning.

Apriani, E., \& Hidayah, J. (2019). The ICT Used by the English Lecturers for Non-English Study Program Students at IAIN Curup. Vision: Journal for Language and Foreign Language Learning, 8(1). https://doi.org/10.21580/vjv8i13280.

Atmojo, A. E. P., \& Nugroho, A. (2020). EFL Classes Must Go Online! Teaching Activities and Challenges during COVID-19 Pandemic in Indonesia. Register Journal, 13(1), 4976. https://doi.org/10.18326/rgt.v13i1.49-76.

Bailey, D. R., \& Lee, A. R. (2020). Learning from Experience in the Midst of COVID-19: Benefits Challenges, and Strategies in Online Teaching. Computer-Assisted Language Learning Electronic Journal, 21(2), 178-198. http://callej.org/journal/21-2/Bailey-Lee2020.pdf.

Bungin, B. (2007). Metodologi Penelitian Kualitatif: Aktualisasi Metodologis ke Arah Ragam Varian Kontemporer. Jakarta: Raja Grafindo Persada.

Flick, U., Kardorff, E. V., \& Steinke, I. (2004). A Companion to Qualitative Research. London: SAGE Publications.

Gao, L. X., \& Zhang, L. J. (2020). Teacher Learning in Difficult Times: Examining Foreign Language Teachers' Cognitions About Online Teaching to Tide Over Covid-19. Frontiers in Psychology, 11(2), 11-14. https://doi.org/10.3389/fpsyg.2020.54965 3.

Hakim, B. (2020). Technology Integrated Online Classrooms and the Challenges Faced by the EFL Teachers in Saudi Arabia during the COVID-19 Pandemic. International Journal of Applied Linguistics \& English Literature, 9(5), 33-39. https://doi.org/10.7575/aiac.ijalel.v.9n.5p.33.

Khatoony, S., \& Nezhadmehr, M. (2020). EFL Teachers' Challenges in the Integration of Technology for Online Classrooms during Coronavirus (COVID-19) Pandemic in Iran. The Asian Journal of English Language \& Pedagogy, 8(2), 89-104. https://doi.org/10.37134/ajelp.vol8.sp.1.2020.

Maulana, D. (2020). EFL Teachers' Perceptions on the Use of ICT in Language Learning. IAIN Salatiga.

Putra, B. A. (2020). English Teacher's Perceptions on English Teaching Difficulties Using Online Platform during Covid-19 Pandemic at SDIT Ar-Risalah Surakarta in 2020/2021 Academic Year. Universitas Muhammadiyah Surakarta.

Sakkir, G., Dollah, S., \& Ahmad, J. (2020). Favorite E-Learning Media in Pandemic Covid-19 Era. Jurnal Studi Guru Dan Pembelajaran, 3(3), 480-482. https://ejournal.my.id/jsgp/article/view/435.

Surakhmad, W. (1990). Pengantar Penelitian Ilmiah: Dasar, Metode dan Teknik. Bandung: Tarsito. 
Todd, R. W. (2020). Teachers' Perceptions of the Shift from the Classroom to Online Teaching. International Journal of TESOL Studies, 2(2), 4-16. https://doi.org/10.46451/ijts.2020.09.02.

Tukan, F. M. E. (2020). Challenges and Strategies Using Application in Teaching OnlineClassroom During Pandemic Covid-19. ELITE Journal, 2(2), 155-172. https://www.elitejournal.org/index.php/ELITE/article/view/43.

Xia, J. (Cecilia), Fielder, J., \& Siragusa, L. (2013). Achieving better peer interaction in online discussion forums: A reflective practitioner case study. Issues in Educational Research, 23(1), 97-113. https://www.researchgate.net/publication/236856263_ Achieving_better_peer_interaction_in_online_discussion_forums_A_reflective_prac titioner_case_study.

Zeid, M. (2004). Metode Penelitian Kepustakaan. Jakarta: Yayasan Obor Indonesia. 